\title{
Contact sensitizer nickel sulfate activates the transcription factors NF-kB and AP-1 and increases the expression of nitric oxide synthase in a skin dendritic cell line
}

Cruz MT, Gonçalo M, Figueiredo A, Carvalho AP, Duarte CB, Lopes MC. Contact sensitizer nickel sulfate activates the transcription factors NF-kB and AP-1 and increases the expression of nitric oxide synthase in a skin dendritic cell line.

Exp Dermatol 2004: 13: 18-26. (C) Blackwell Munksgaard, 2004

Abstract: Nuclear factor kappa B (NF-kB) and activating protein-1 (AP-1) transcription factors are ubiquitously expressed signaling molecules known to regulate the transcription of a large number of genes involved in immune responses, namely the inducible isoform of nitric oxide synthase (iNOS). In this study, we demonstrate that a fetal skin-derived dendritic cell line (FSDC) produces nitric oxide (NO) in response to the contact sensitizer nickel sulfate $\left(\mathrm{NiSO}_{4}\right)$ and increases the expression of the iNOS protein, as determined by immunofluorescence and Western blot analysis. The sensitizer $\mathrm{NiSO}_{4}$ increased cytoplasmic iNOS expression by $31.9 \pm 10.3 \%$ and nitrite production, as assayed by the Griess reaction, by $27.6 \pm 9.5 \%$. Electrophoretic mobility shift assay (EMSA), showed that $30 \mathrm{~min}$ of FSDC exposure to $\mathrm{NiSO}_{4}$ activates the transcription factor NF-kB by $58.2 \pm 7.0 \%$ and $2 \mathrm{~h}$ of FSDC exposure to $\mathrm{NiSO}_{4}$ activates the transcription factor AP- 1 by $26.0 \pm 1.4 \%$. Together, these results indicate that $\mathrm{NiSO}_{4}$ activates the NF-kB and AP-1 pathways and induces iNOS expression in skin dendritic cells.

\author{
M. Teresa Cruz ${ }^{1,2}$ Margarida \\ Gonçalo $^{3}$, Américo Figueiredo ${ }^{3}$, \\ Arsélio P. Carvalho ${ }^{2}$, Carlos B. \\ Duarte $^{2}$ and M. Celeste Lopes ${ }^{1,2}$ \\ ${ }^{1}$ Faculdade de Farmácia, \\ ${ }^{2}$ Centro de Neurociências e Biologia Celular, \\ ${ }^{3}$ Faculdade de Medicina (Serviço de \\ Dermatologia), Universidade de Coimbra, \\ Coimbra, Portugal
}

Key words: NO - iNOS - skin dendritic cell contact sensitizer - nickel sulfate - NF-kB AP-1

M. Teresa de Teixeira Cruz, Centro de Neurociências e Biologia Celular, Departamento de Zoologia, Universidade de Coimbra, 3004517 Coimbra, Portugal.

Tel.: + 351-239-480237/6

Fax: +351-239-480217

e-mail: trosete@ff.uc.pt

Accepted for publication 19 December 2002

\section{Introduction}

Skin dendritic cells (DCs) play an important role in the initiation of the allergic contact reaction by primary activation of naive specific $\mathrm{T}$ cells. Critical events of the sensitization phase include the activation of resident DC in the epidermis and dermis $(1,2)$. Immature skin dendritic cells capture and process the antigens and then migrate to $\mathrm{T}$-cell areas of lymphoid organs where they lose antigen-processing activity and mature to become potent immunostimulatory cells. Dendritic-cell differentiation and maturation require the activation of the mitogen-activated protein kinase (MAPK)

Abbreviations: AP-1, activating protein-1; DC, dendritic cell; DNFB, 2,4-dinitrofluorobenzene; EMSA, electrophoretic mobility shift assay; FSDC, fetal skin dendritic cell line; IkB, inhibitor of NF-kB; iNOS, inducible nitric oxide synthase; LPS, lipopolysaccharide; MAPK, mitogen activated protein kinase; MHC II, major histo-compatibility complex class II molecules; NF-kB, transcription nuclear factor kappa $\mathrm{B} ; \mathrm{NiSO}_{4}$, nickel sulfate; $\mathrm{NO}$, nitric oxide.
(3) and the transcription nuclear factor kappa B (NF-kB) (4-7).

Nickel is the most frequent cause of contact allergy (8). This hapten significantly increases the expression of dendritic cell-surface markers essential for antigen presentation, such as the major histocompatibility complex class II molecules (MHC II) and costimulatory molecules, and increases the antigen-presenting function of these cells $(9-11,3)$. However, the signal transduction pathways involved in nickel-induced DC maturation are still poorly characterized.

We have previously reported that in a fetal skin dendritic cell line (FSDC) exhibiting functional characteristics of a DC precursor, lipopolysaccharide (LPS) and granulocyte-macrophage colonystimulating factor activate the transcription factor NF-kB and induce the expression of type II isoform of nitric oxide synthase (iNOS) $(12,13)$. Nitric oxide (NO) is a highly reactive radical produced from the amino acid L-arginine, by the 
enzyme NO synthase (14), and appears to be involved in skin growth and remodeling (15-18), in skin inflammatory processes (19-21) and in modulating antigen presentation (22-25).

The transcription nuclear factor kappa B (NF$\mathrm{kB})$ and the transcription factor activating protein 1 (AP-1) are ubiquitous transcription factors and pleiotropic regulators of the inducible expression of many genes that encode proteins involved in the modulation of inflammatory and host defense processes in eukaryotic cells, namely the iNOS gene $(26,27)$. The promoter region of the iNOS gene contains binding sites for the transcription factors NF-kB and AP-1 $(28,29)$. In resting cells, NF-kB proteins (p50, p52, p65/RelA, RelB, and c-Rel) are localized in the cytosol in association with the inhibitory proteins called $\mathrm{IkB}$. Cell activation by various stimuli results in IkB protein phosphorylation and degradation, which in turn leads to the translocation of NF-kB proteins to the nucleus, where they up-regulate gene expression(30). The transcription factor AP-1 is composed of homo and heterodimeric complexes of Jun (c-Jun, Jun B, Jun D), Fos (c-Fos, Fos B, Fra-1 and Fra-2) and activating transcription factor (ATF) family proteins, and regulates gene transcription by interacting with the DNA-regulatory elements. Depending on the composition of the dimmer, different sequence elements are preferentially recognized (27).

The aim of this study was to know whether the contact sensitizer nickel sulfate $\left(\mathrm{NiSO}_{4}\right)$ induced iNOS expression and NO production in a FSDC. Moreover, we also studied whether $\mathrm{NiSO}_{4}$ activates the transcription factors NF-kB and AP-1 in skin DCs.

\section{Materials and Methods \\ Materials}

Nickel sulfate was from Sigma Chemical Co. (St. Louis, MO). The rabbit antimouse iNOS polyclonal antibody was purchased from Transduction Laboratories (Lexington, KY), and the rabbit antihuman NF-kB p65 was from Serotec (Oxford, UK). The fluorescein isothiocyanate (FITC)-conjugated swine antirabbit immunoglobulin was from DAKO (Copenhagen, Denmark). The mounting medium for fluorescence, Vectashield, was obtained from Vector Laboratories, Inc. (Burlingame, CA). The NF-kB and AP-1 consensus oligonucleotide, the rabbit antimouse NF-kB RelB, the rabbit antihuman NF-kB p50, the goat antimouse NF-kB cRel and the rabbit antimouse NF-kB p52 were obtained from Santa Cruz Biotechnology (Santa Cruz, CA). The rabbit antibodies against the proteins Fra-1, Fra-2, c-Jun, Fos B, ATF-2, Jun B and Jun D and the mouse antibody against the c-Fos protein were obtained from Santa Cruz Biotechnology (Santa Cruz). The horseradish peroxidase-conjugated goat antimouse was from Pierce (Rockford, IL). The ${ }^{32} \mathrm{P}-l a b e l e d$ $\gamma$-ATP, the T4 polynucleotide kinase, the poly (dI-dC)-poly (dI-dC), ECL Western blotting analysis system, horseradish peroxidase-conjugated donkey antirabbit immunoglobulin and the X-ray films were from Amersham Biosciences (Carnaxide, Portugal). The fetal calf serum was from Biochrom KG (Berlin, Germany) and trypsin from Invitrogen (Paisley, UK). Triton ${ }^{\circledR}$ $\times 100$ and paraformaldehyde were from VWR International/ Merck Eurolab (Lisboa, Portugal). The protease inhibitor cocktail and the mouse monoclonal antibody against actin were from Roche (Carnaxide, Portugal). All other reagents were from Sigma Chemical Co.

\section{Cell culture}

The fetal mouse skin dendritic cell line FSDC was kindly supplied by $\mathrm{Dr}$ G. Girolomoni (31). The cells were cultured in endotoxin free Iscove's modified Dulbeccos' medium supplemented with $10 \%(\mathrm{v} / \mathrm{v})$ fetal calf serum, $1 \%(\mathrm{w} / \mathrm{v})$ glutamine, $3.02 \mathrm{~g} / 1$ sodium bicarbonate, $100 \mu \mathrm{g} / \mathrm{ml}$ of streptomycin and $100 \mathrm{U} / \mathrm{ml}$ of penicillin. For Western blot and electrophoretic mobility shift assay (EMSA) analysis, the FSDCs were plated at $2 \times 10^{6}$ cells/wells in six-well culture plates for $24 \mathrm{~h}$ before treatment, whereas for nitrite measurements the cells were plated at $0.2 \times 10^{6}$ cells/wells in 48-well culture plates. For immunofluorescence analysis, the FSDC cells were grown on a Laboratory-Tek chamber slide with cover $\left(0.2 \times 10^{6}\right.$ cells/slide $)$ for $24 \mathrm{~h}$ before treatment.

\section{Nitrite measurement}

The production of NO was accessed as the accumulation of nitrite $\left(\mathrm{NO}_{2}^{-}\right)$in the culture supernatants, using a colorimetric reaction with the Griess reagent (32). Briefly, after FSDC stimulation with different concentrations of $\mathrm{NiSO}_{4}(1-100 \mu \mathrm{g} / \mathrm{ml})$, for $48 \mathrm{~h}$, the culture supernatants were collected and diluted with equal volumes of the Griess reagent $[0.1 \%(\mathrm{w} / \mathrm{v}) \mathrm{N}$-(1-naphthyl) ethylenediamine dihydrochloride, $1 \%(\mathrm{w} / \mathrm{v})$ sulphanilamide: $5 \%(\mathrm{w} / \mathrm{v})$ $\left.\mathrm{H}_{3} \mathrm{PO}_{4}\right]$ for $10 \mathrm{~min}$. The absorbance at $550 \mathrm{~nm}$ was measured, after a 20-min incubation, in an automated plate reader (SLT, Salzburg, Austria). The nitrite concentration was determined from a sodium nitrite standard curve.

\section{Western blot analysis}

For immunodetection of iNOS, cells were treated with culture medium (control) or with $\mathrm{NiSO}_{4}(100 \mu \mathrm{g} / \mathrm{ml})$. After treatment, cells were washed with PBS, and total cell lysates were obtained after harvesting the cells in sonication buffer containing $0.32 \mathrm{M}$ of sucrose, $10 \mathrm{mM}$ of Tris- $\mathrm{HCl}, \mathrm{pH} 7.5,1 \mathrm{mM}$ of ethylenediaminetetraacetic acid, $1 \mathrm{mM}$ of dithiothreitol, $0.1 \mathrm{mM}$ of phenylmethylsulfonylfluoride and the protease inhibitor cocktail. Then, the lysates were incubated on ice for $30 \mathrm{~min}$ and sonicated on ice at low amplitude (four times for $4 \mathrm{~s}$ at $20 \mu \mathrm{m}$ peak to peak) to disrupt the cells. Protein concentration was determined using the bicinchoninic acid method. Protein samples were separated on a $10 \%$ (v/v) SDS-PAGE, and transferred to a polyvinylidene difluoride (PVDF) membrane. The membrane was blocked with 5\% (w/v) dry milk in Tris-buffered saline with $0.1 \%$ (v/v) Tween 20, for $1 \mathrm{~h}$. The level of iNOS protein was detected using a rabbit polyclonal antimouse iNOS antibody $(1: 2000)$ for $1 \mathrm{~h}$, followed by incubation with a horseradish peroxidase-conjugated swine antirabbit antibody $(1: 5000)$. The immunocomplexes were visualized by the enhanced chemiluminescence (ECL) chemiluminescence method. To demonstrate equivalent protein loading the membrane was stripped and reprobed with an antiactin antibody $(1: 10000)$.

\section{Immunofluorescence microscopy}

For immunofluorescence analysis, FSDC cells grown on the Laboratory-Tek chamber slide with cover $\left(0.2 \times 10^{6}\right.$ cells/slide $)$ were treated for $24 \mathrm{~h}$ with $\mathrm{NiSO}_{4}(50$ and $100 \mu \mathrm{g} / \mathrm{ml})$. The cells were then washed with PBS and fixed with PBS containing $4 \%$ (w/v) sucrose and $4 \%(\mathrm{w} / \mathrm{v})$ paraformaldehyde for $15 \mathrm{~min}$, and then 
the FSDCs were permeabilized in PBS containing $1 \%(\mathrm{v} / \mathrm{v})$ Triton ${ }^{\mathbb{B}} \times 100$ for $10 \mathrm{~min}$. Non-specific binding was blocked by incubating the cells with PBS supplemented with normal swine serum $(1: 20)$ and with $0.5 \%(\mathrm{w} / \mathrm{v})$ BSA for $45 \mathrm{~min}$ at room temperature. Cells were then incubated for $90 \mathrm{~min}$ at room temperature with a rabbit polyclonal antibody directed against mouse iNOS $(10 \mu \mathrm{g} / \mathrm{ml})$. After rinsing with PBS the cells were incubated with FITC-conjugated swine antirabbit immunoglobulin (1:40 dilution) in $0.5 \%$ BSA-PBS for $45 \mathrm{~min}$. The chamber slide was rinsed and mounted with the mounting medium for fluorescence, Vectashield. Cells labeled with FITC-anti iNOS were photographed on a Zeiss Axioskop microscope (Zeiss, Oberkochen, Germany). Control experiments consisted of processing the same preparations as described, except for omitting the primary antibody, and resulted in no specific staining.

\section{Electrophoretic mobility shift assay}

The FSDC cells were treated for $15 \mathrm{~min}, 30 \mathrm{~min}$ and $2 \mathrm{~h}$ with $\mathrm{NiSO}_{4}(100 \mu \mathrm{g} / \mathrm{ml})$. The cells were then washed with PBS and lysed in $10 \mathrm{mM}$ of $\mathrm{NaCl}, 3 \mathrm{mM}$ of $\mathrm{MgCl}_{2}, 0.5 \%$ (v/v) Nonidet P-40, $1 \mathrm{mM}$ of dithiothreitol, $0.1 \mathrm{mM}$ of phenylmethylsulfonylfluoride, $10 \mathrm{mM}$ of Tris- $\mathrm{HCl}(\mathrm{pH} 7.5)$ and the protease inhibitor cocktail. The lysates were incubated on ice for $15 \mathrm{~min}$ and centrifuged at $2300 \times \mathrm{g}$, for $10 \mathrm{~min}$. The pellet obtained was resuspended in $300 \mathrm{mM}$ of $\mathrm{NaCl}, 3 \mathrm{mM}$ of $\mathrm{MgCl}_{2}, 20 \%$ (v/v) glycerol, $1 \mathrm{mM}$ of dithiothreitol, $0.1 \mathrm{mM}$ of phenylmethylsulfonylfluoride, $0.2 \mathrm{mM}$ of EDTA, $20 \mathrm{mM}$ of HEPES buffer $(\mathrm{pH} 7.5)$ and the protease inhibitor cocktail, incubated on ice for $1 \mathrm{~h}$, and centrifuged at $12000 \times g$, for $20 \mathrm{~min}$. The supernatant containing the nuclear proteins was collected, and protein concentration was determined using the bicinchoninic acid solution. The EMSA method used was similar to that described previously (26), with slight modifications. The probes consisted of a double-stranded oligonucleotide containing the consensus binding sequence for NF-kB (5'-AGT TGA GGG GAC TTT CCC AGG C-3'), or for AP-1(5'-CGC TTG ATG ACT CAG CCG GAA-3') endlabeled with $\left[\gamma-{ }^{32} \mathrm{P}\right] \mathrm{ATP}$ using T4 polynucleotide kinase. Typical binding reactions consisted of $15 \mu \mathrm{g}$ of nuclear extract, $\sim 150,000$ c.p.m. of $\left[\gamma^{32} \mathrm{P}\right]$-labeled oligonucleotide, and $100 \mu \mathrm{g} / \mathrm{ml}$ of poly (dI-dC).poly (dI-dC), in a buffer containing $20 \mathrm{mM}$ of HEPES (pH 7.9), $1 \mathrm{mM}$ of $\mathrm{MgCl}_{2}, 4 \%$ (w/v) Ficoll $400,0.5 \mathrm{mM}$ of dithiothreitol, $50 \mathrm{mM}$ of $\mathrm{KCl}$, and $1 \mathrm{mg} / \mathrm{ml}$ of BSA, and were incubated at room temperature for $45 \mathrm{~min}$. Binding reactions were separated on $7 \%(\mathrm{v} / \mathrm{v})$ non-denaturing polyacrylamide gels, in a buffer system containing $0.044 \mathrm{M}$ of Tris-Base (pH 8.0), $44.5 \mathrm{mM}$ of boric acid and $1 \mathrm{mM}$ of EDTA, at a constant voltage of $150 \mathrm{~V}$, for $2 \mathrm{~h}$ and $15 \mathrm{~min}$ at room temperature. The gels were transferred to Whatman paper, dried, and subjected to autoradiography. In competition experiments, an unlabeled oligonucleotide was added to the nuclear extracts for $30 \mathrm{~min}$ before addition of a radiolabeled probe. To detect supershifted bands, specific antibodies $(2 \mu \mathrm{g})$ against the NF-kB and AP-1 proteins were incubated with the nuclear extracts for 30 min before addition of the radiolabeled probe.

\section{Data analysis}

Results are presented as mean \pm SEM of the indicated number of experiments. Mean values were compared using the Student's two-tailed unpaired $t$-test.

\section{Results}

Nickel sulfate increases the production of nitric oxide and the expression of iNOS in FSDC cells

The enzymatic production of NO by the FSDCs was evaluated by the measurement of nitrite concentration in the culture medium. As shown in Fig. 1, stimulation of the cells with $\mathrm{NiSO}_{4}(1-100$ $\mu \mathrm{g} / \mathrm{ml}$ ) for $48 \mathrm{~h}$ caused a dose-dependent increase in nitrite production, from $100 \%$ when the FSDCs were incubated with culture medium alone to $127.6 \pm 9.5 \%$ when the FSDCs were incubated with $25 \mu \mathrm{g} / \mathrm{ml}$ of $\mathrm{Ni}(P<0.05)$. The assay of cellular MTT reduction did not show any significant toxic effect induced by $\mathrm{NiSO}_{4}$ for the concentrations used in these experiments (data not shown).

Western blot was used to examine whether $\mathrm{NiSO}_{4}$ regulates the expression of iNOS protein $(130 \mathrm{kDa})$. As indicated in Fig. 2(a), non-stimulated cells express iNOS (lane 1), but the expression of the protein increased to $131.9 \pm 10.3 \%$ of the control upon stimulation with $100 \mu \mathrm{g} / \mathrm{ml}$ of $\mathrm{NiSO}_{4}$, for $24 \mathrm{~h}$ (Fig. 2b) $(P<0.05)$. The basal expression of the iNOS protein in the control cells was probably a result of the presence of FCS $(10 \%)$ in the culture medium, which per se activates the cells.

\section{Immunocytochemistry of the iNOS protein induction by nickel sulfate in FSDCs}

Immunofluorescent labelling of FSDC cells with the antiiNOS polyclonal antibody was markedly increased in cells stimulated with $50 \mu \mathrm{g} / \mathrm{ml}$ of $\mathrm{NiSO}_{4}$ (Fig. 3b) and $100 \mu \mathrm{g} / \mathrm{ml}$ of $\mathrm{NiSO}_{4}$ (Fig. 3c), as compared with the cells maintained in culture medium (Fig. 3a). These results are in agreement with those obtained by Western blot (Fig. 2) and indicate that the expression of iNOS is up-regulated by the sensitizer $\mathrm{NiSO}_{4}$ in FSDCs.

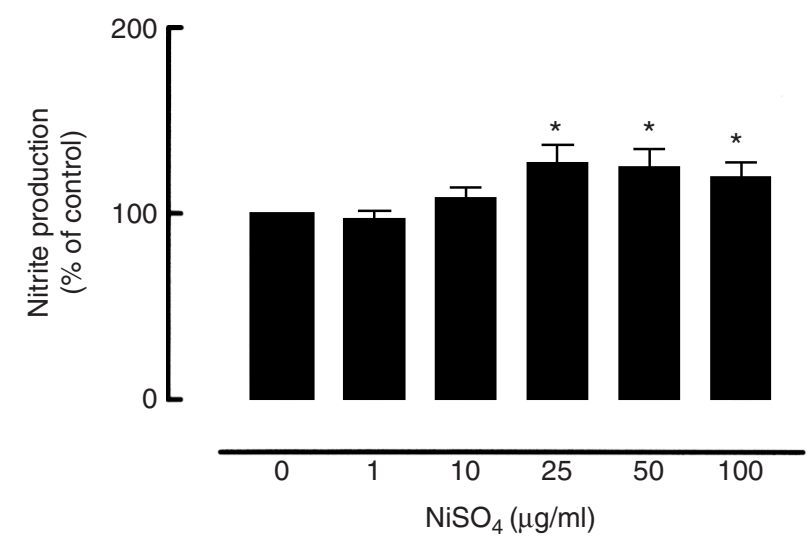

Figure 1. The sensitizer nickel sulfate increased nitrite production in the fetal skin-derived dendritic cell line. Fetal skin-derived dendritic cell line cells $\left(0.2 \times 10^{6}\right.$ cells $)$ were maintained in culture medium (control) or were incubated for $48 \mathrm{~h}$ with different concentrations of nickel sulfate $(1-100 \mu \mathrm{g} / \mathrm{ml})$. Nitrite levels in the culture supernatants were detected by the Griess reaction, as described in experimental procedures. Each value represents the mean \pm SEM from eight experiments performed in duplicate $\left({ }^{*} P<0.05\right)$. 
(a)

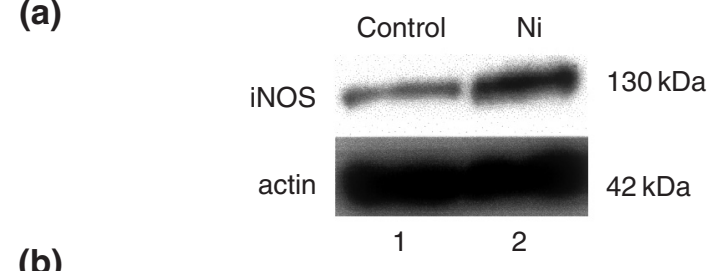

(b)

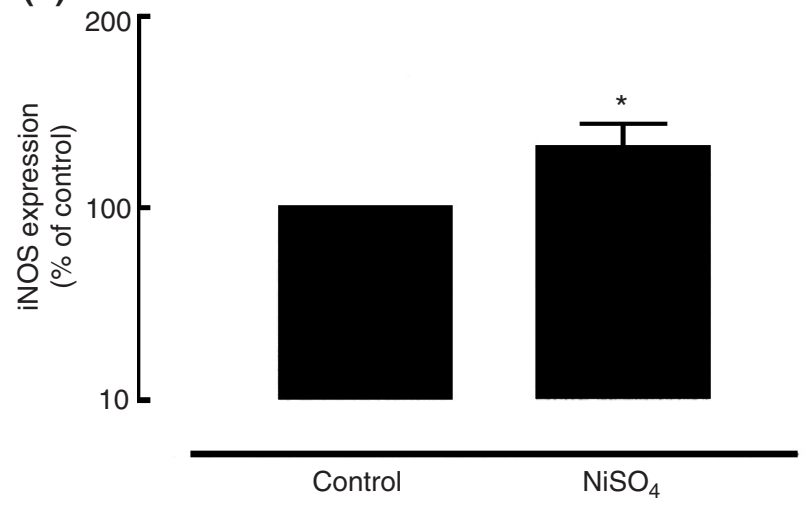

Figure 2. The sensitizer nickel sulfate $\left(\mathrm{NiSO}_{4}\right)$ increased the isoform of nitric oxide synthase protein expression in the fetal skin-derived dendritic cell line. Fetal skin-derived dendritic cell line cells $\left(2 \times 10^{6}\right.$ cells $)$ were incubated for $24 \mathrm{~h}$ in culture medium alone (control, lane 1) or in the presence of $100 \mu \mathrm{g} / \mathrm{ml}$ of $\mathrm{NiSO}_{4}$ (lane 2). Total cell extracts were electrophoresed through SDSPAGE, transferred to PVDF membranes and subjected to Western blot analysis using an antiiNOS antibody. The membrane was stripped and reprobed with an antiactin antibody to confirm equal protein loading (a). The bands were quantified with an image analyzer. Each value represents the mean \pm SEM from four experiments $\left({ }^{*} P<0.05\right)$ (b). iNOS $=$ inducible nitric oxide synthase.
Nickel sulfate induces NF-kB and AP-1 binding to DNA in FSDC cells

As the promoter region of the iNOS gene contains binding sites for NF-kB and AP-1 $(28,29)$ we examined whether the contact sensitizer nickel activates these two transcription factors.

The FSDCs were stimulated with $\mathrm{NiSO}_{4}$ $(100 \mu \mathrm{g} / \mathrm{ml})$ for $15 \mathrm{~min}$ and $30 \mathrm{~min}$, and maximal NF-kB binding to DNA (Fig. 4) was observed within a period of $30 \mathrm{~min}$ (lane 3 ). As indicated in Fig. 4(a), the NF-kB binding to DNA increased to $158.2 \pm 7.0 \%$ of the control upon stimulation with $100 \mu \mathrm{g} / \mathrm{ml}$ of $\mathrm{NiSO}_{4}$, for $30 \mathrm{~min}(P<0.001)$. Supershift experiments using antibodies against the subunits of NF-kB indicated that the antibodies against p65 (lane 6), RelB (lane 7) and cRel (lane 8) proteins decreased NF-kB complex formation (Fig. 4b). Unlabeled oligonucleotide (100-fold in excess) was used as a control for the gel shift assays (lane 2), and inhibited the NF-kB complex formation. In contrast, the antibodies against the subunits of NF-kB p50 (lane 4) and p52 (lane 5) were without effect on NF-kB complex formation (Fig. 4b).

As AP-1 activation requires de novo protein synthesis, we incubated FSDC cells with the contact sensitizer for 1 and $2 \mathrm{~h}$. Figure 5(a) shows that stimulation of FSDCs with $\mathrm{NiSO}_{4}(100 \mu \mathrm{g} / \mathrm{ml})$ increases AP-1 binding to DNA within a period of $2 \mathrm{~h}$ (from $100 \%$ in control cells to $126 \pm 1.4 \%$, $P<0.001)$. Supershift experiments using antibodies against the different proteins of AP-1 (Fra-1,
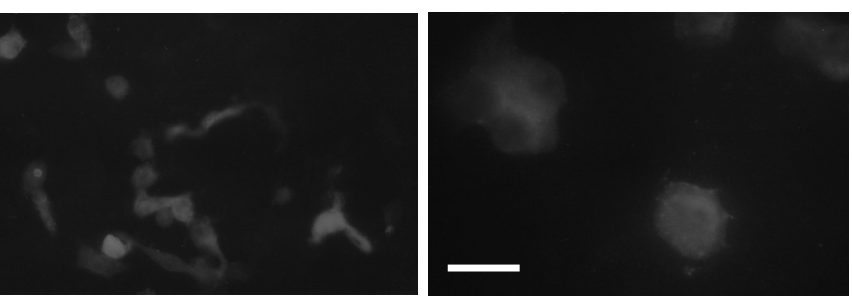

(a) Control

Figure 3. Immunocytochemistry of the isoform of nitric oxide synthase protein increased by the sensitizer nickel sulfate in the fetal skin-derived dendritic cell line. Fetal skin-derived dendritic cell line cells $\left(0.2 \times 10^{6}\right.$ cells $)$ were maintained for $24 \mathrm{~h}$ in culture medium in the absence (a) or presence of $50 \mu \mathrm{g} / \mathrm{ml}$ of nickel sulfate (b), or $100 \mu \mathrm{g} / \mathrm{ml}$ of nickel sulfate (c). Immunostaining was performed as described in Materials and Methods. Scale bars $=25$ micrometers (left panelmagnification $\times 100$; right panelmagnification $\times 250$ ).
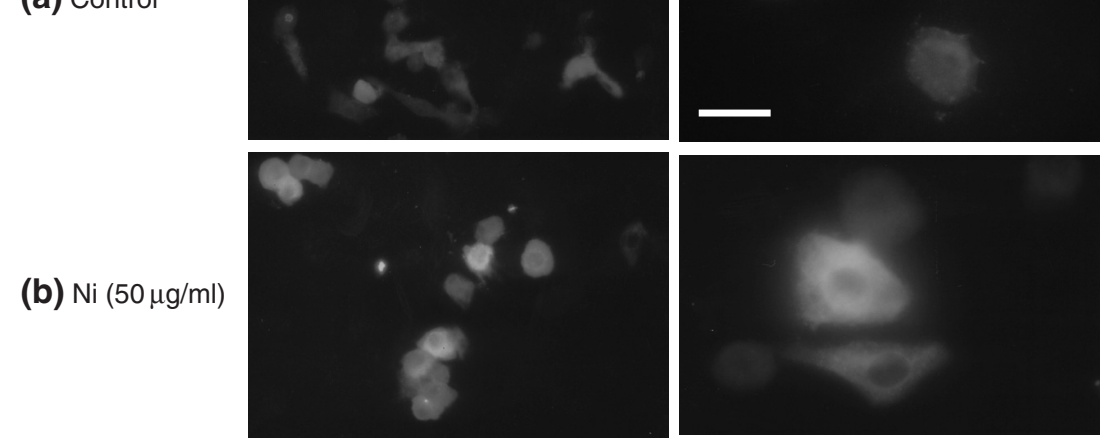

(b) $\mathrm{Ni}(50 \mu \mathrm{g} / \mathrm{ml})$
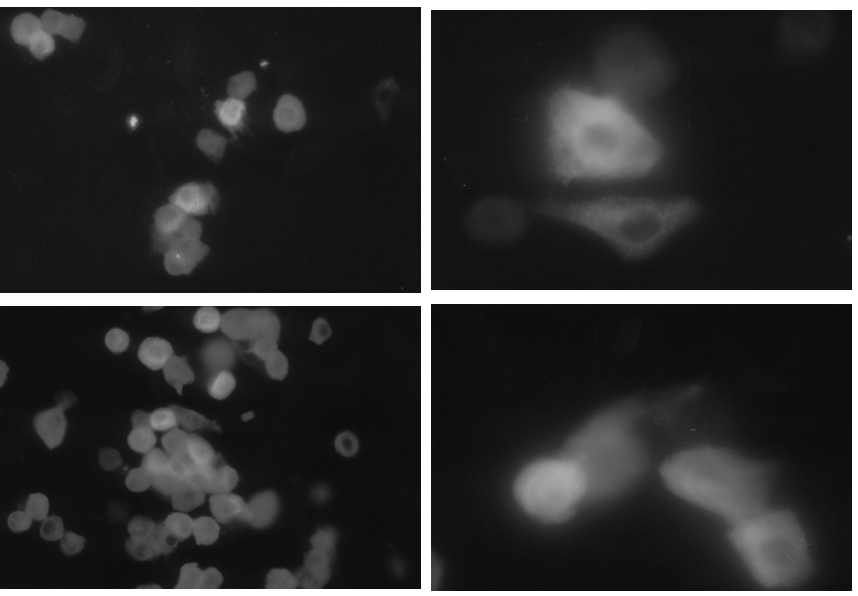
Cruz et al.

(a)

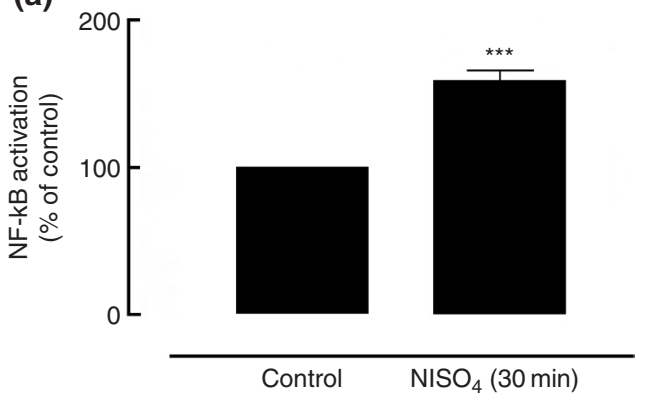

(b)
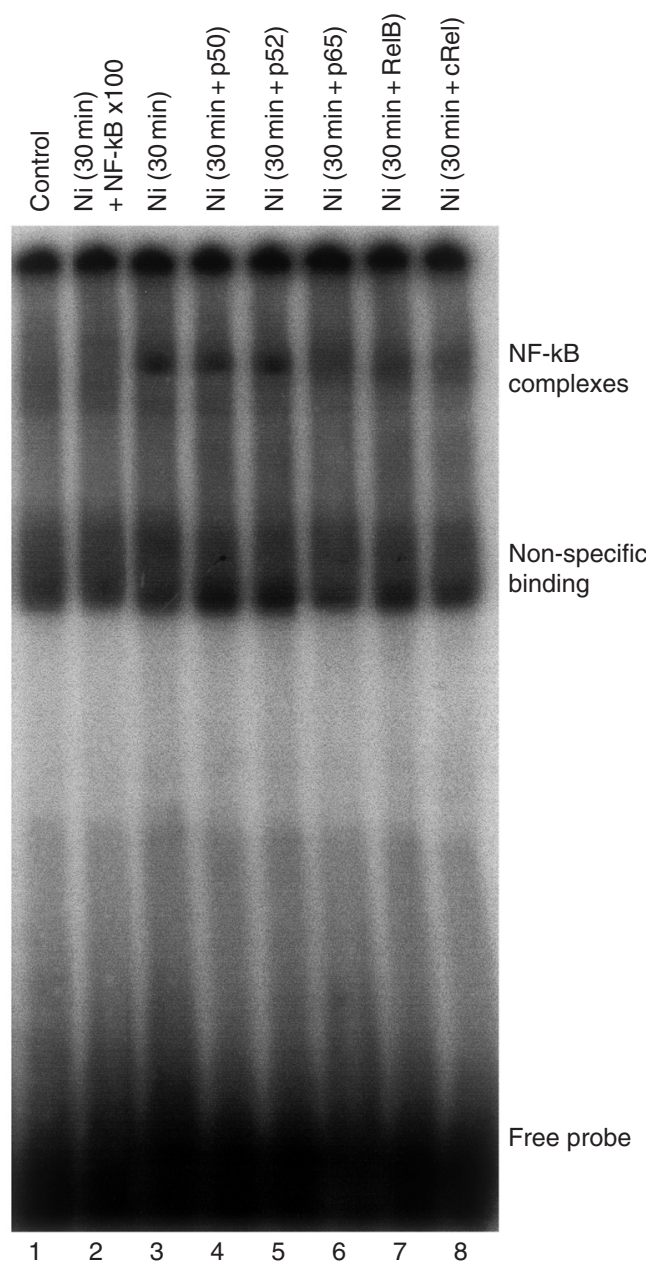

Figure 4. The sensitizer nickel sulfate induced nuclear factor kappa activation in fetal skin-derived dendritic cell line cells. Fetal skin-derived dendritic cell line cells $\left(2 \times 10^{6}\right.$ cells $)$ were incubated for $30 \mathrm{~min}$ in culture medium alone (control, lane 1) or in the presence of $100 \mu \mathrm{g} / \mathrm{ml}$ of nickel sulfate (lane 3). Nuclear extracts were subjected to electrophoretic mobility shift assay analysis, as described in experimental procedures. These bands were quantified with an image analyzer. Each value represents the mean \pm SEM from four experiments $(* * * P<0.001)$ (a). Supershift experiments were performed using specific antip50, antip52, antip65, antiRelB and anticRel antibodies (lanes 4-8). To demonstrate specificity of induced bands, binding was carried out in the presence of a molar excess $(\times 100)$ of non-radioactive oligonucleotide containing the nuclear factor kappa B (NF-kB) consensus sequence (lane 2). The gel shown is representative of two gels yielding identical results (b).

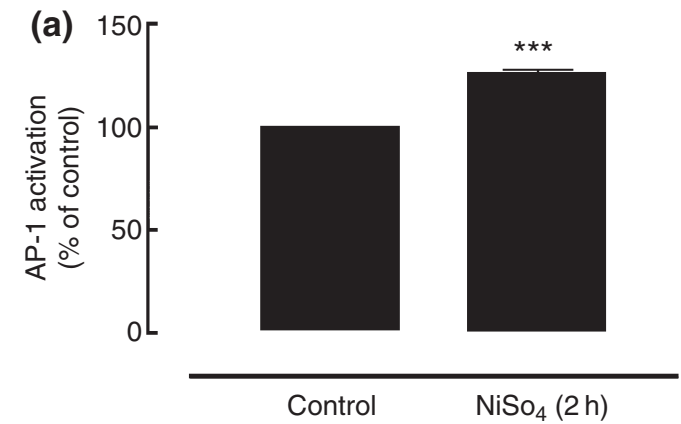

(b)
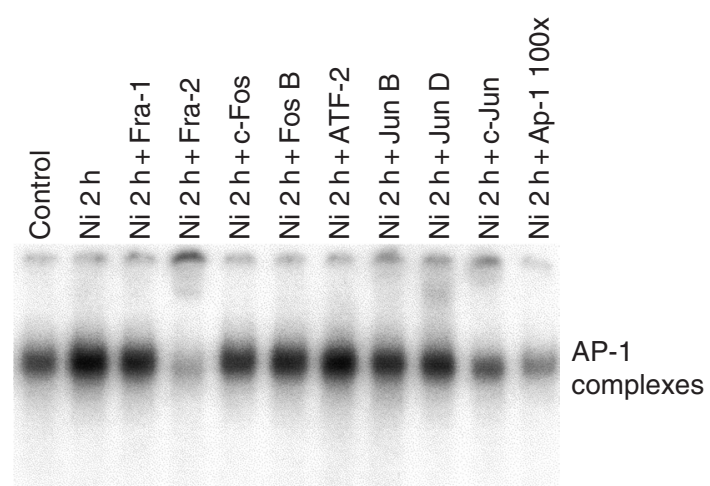

Non-specific binding

Free probe

Figure 5. The sensitizer nickel sulfate induced activating protein-1 (AP-1) activation in fetal skin-derived dendritic cell line cells. Fetal skin-derived dendritic cell line cells $\left(2 \times 10^{6}\right.$ cells $)$ were incubated for $2 \mathrm{~h}$, for the time periods indicated, in culture medium alone (control, lane 1) or in the presence of $100 \mu \mathrm{g} / \mathrm{ml}$ of nickel sulfate (lane 2). Nuclear extracts were subjected to electrophoretic mobility shift assay analysis, as described in experimental procedures. These bands were quantified with an image analyzer. Each value represents the mean \pm SEM from three experiments $(* * * P<0.001)$ (a). Supershift experiments were performed using specific antiFra-1, antiFra-2, antic-Fos, antiFos B, antiATF-2, antiJun B, antiJun D and antic-Jun antibodies (lanes 3-10). To demonstrate specificity of induced bands, binding was carried out in the presence of a molar excess $(\times 100)$ of non-radioactive oligonucleotide containing the AP-1 consensus sequence (lane 11). The gel shown is representative of two gels yielding identical results (b). 
Fra-2, c-Fos, Fos B, ATF-2, Jun B, Jun D and c-Jun) were performed, and indicated that the antibodies against Fra-1, Fra-2, c-Fos, Fos B (lanes 3-6), Jun B, Jun D and c-Jun (lanes 8-10) proteins decrease AP-1 complex formation (Fig. 5b). In contrast, the antibody against the protein ATF-2 (lane 7) was without effect on AP-1 complex formation (Fig. 5b). Unlabeled oligonucleotide (100-fold in excess) was used (lane 11) as a control for the gel shift assays, and inhibited AP-1 complex formation (Fig. 5b).

\section{Discussion}

In the present work, we have shown that the contact sensitizer nickel sulfate $\left(\mathrm{NiSO}_{4}\right)$ increases iNOS expression and NO production in a FSDC line (Figs 1-3). Moreover, exposure of FSDCs to $\mathrm{NiSO}_{4}$ induced NF-kB and AP-1 binding to DNA (Figs 4 and 5).

The list of immunological agents known to induce $\mathrm{iNOS}$ gene expression in vivo and in vitro has been growing in recent years (14), but few reports exist concerning the effect of the contact sensitizer nickel on NOS. Nickel was shown to inhibit the constitutive neuronal NOS activity $(33,34)$, whereas in LPS- and cytokine-stimulated macrophages the sensitizer nickel significantly increased NO production $(35,36)$.

The intracellular signaling pathways by which $\mathrm{NiSO}_{4}$ induces iNOS expression in DCs are not known. We have previously reported that in FSDCs, LPS and GM-CSF induce IkB- $\alpha$ degradation, the translocation of NF-kB proteins into the nucleus and the expression of iNOS $(12,13)$. However, NO production induced by nickel $(50 \mu \mathrm{g} / \mathrm{ml})$ was 5.1- and 1.4-fold lower than that produced by FSDCs stimulated with LPS $(5 \mu \mathrm{g} / \mathrm{ml})$ and GMCSF (200 ng/ml), respectively (37). Lipopolysaccharide was shown to stimulate the production of cytokines (38) and to induce maturation of human monocyte-derived dendritic cells (39). Therefore, LPS may cause NO production both directly and indirectly, via the synthesis of cytokines that also stimulate NO production. Interestingly, the amount of NO production induced by nickel was slightly higher (1.2-fold) than that produced by FSDCs in response to TNF- $\alpha$ (37). These differences in the amount of NO produced by FSDCs stimulated with LPS, GM-CSF, TNF- $\alpha$ and the contact sensitizer nickel may be a result of the activation of distinct signalling pathways, which in turn increase the iNOS protein expression. Accordingly, we demonstrated previously that LPS induced iNOS expression through the Janus kinase signalling pathway (12), in contrast to recent results showing that contact sensitizers do not activate this signalling pathway (40).

As the promoter region of the iNOS gene contains binding sites for NF-kB and AP-1 $(28,29)$ it is possible that, in FSDCs, nickel sulfate increases the iNOS expression through NF-kB or/and AP-1 activation. Accordingly, our results show that $\mathrm{NiSO}_{4}$ induced activation of the transcriptor factors NF-kB and AP-1 (Figs 4 and 5). Nuclear factor-kB activation by nickel was also reported in endothelial cells $(41,42)$. Moreover, in human airway epithelial cells, nickel-induced interleukin-8 expression was shown to be dependent on AP-1 (43) and, in epithelial cells, nickel activates AP-1 through an oxidant-independent pathway (44).

Nickel was found to increase the production of tumour necrosis factor $\alpha$ in DCs and to up-regulate the expression of $\mathrm{MHC}$, of the costimulatory molecule CD80 in DCs $(3,9,10)$, and of the endothelial adhesion molecules in endothelial cells (45). The genes that codified those proteins contain NF-kB binding sites in their promoter enhancer regions (46).

Most of the NF-kB inducers appear to rely on the production of intracellular reactive oxygen species, and the activity of the transcription factor AP-1 is modulated by the intracellular redox state (47). As nickel compounds are also able to cause generation of reactive oxygen species $(48,49)$, it is possible that in FSDCs the sensitizer nickel generates reactive oxygen species, which in turn activates the NF-kB and AP-1 transcription factors that bind to the iNOS gene promoter, thus inducing iNOS protein expression. Accordingly, nickel compounds are able to induce nuclear factor of activated $\mathrm{T}$ cells (NFAT), and the mechanism of NFAT activation seems to be mediated by the generation of hydrogen peroxide (50). Another mechanism of signal transduction induced by nickel involves the activation of the p38 mitogenactivated protein kinase (MAPK) $(3,42)$. The p38 MAPK pathway was shown to contribute to AP1- and NF-kB-mediated transactivation (51-53). These results also suggest that in FSDCs, nickel may also activate protein kinases, namely p38 MAPK, which in turn induce NF-kB activation and iNOS expression.

We have previously reported that in FSDCs the strong sensitizer 2,4-dinitrofluorobenzene (DNFB) induces the degradation of the inhibitor of NF-kB, IkB- $\alpha$ and stimulates the translocation of the NF-kB proteins into the nucleus (54), whereas the nonsensitizer 2,4-dichloronitrobenzene was without effect (data not shown). These results indicate that in skin DCs the NF-kB is a pivotal signalling pathway activated by contact sensitizers. 
Accordingly, it was recently demonstrated that effective antigen presentation by DCs is NF-kB dependent (55) and that the NF-kB proteins are involved in $\mathrm{DC}$ differentiation and maturation $(4-7,56)$. The NF-kB signal transduction pathway is also involved in the survival and maturation of LPS-stimulated human monocyte-derived dendritic cells (39). The NF-kB member RelB is also involved in DC differentiation $(57,58)$ and in the transactivation of genes of central importance for functional antigen-presenting cells (59-61).

Although the strong sensitizer 2,4-dinitrofluorobenzene (DNFB) induced the NF-kB pathway (54) it did not induce iNOS expression in FSDCs (data not shown), in contrast with the results obtained in this work, in which the sensitizer nickel sulfate induced iNOS expression (Figs 2 and 3). Moreover, the strong sensitizer DNFB induced p50, p52 and RelB translocation from the cytosol to the nucleus of FSDCs, and was without effect on cRel protein (54), in contrast with the results obtained in this work, in which the sensitizer nickel sulfate activated p65, cRel and RelB proteins (Fig. 4). This differential activation of nuclear factor kappa $\mathrm{B}$ subunits in response to the different contact sensitizers DNFB and nickel may explain the different effects of those sensitizers on iNOS expression. Accordingly, the NF-kB displays the capacity to activate, in a cell-and stimulus-specific manner, only a subset of the total repertoire of NF-kBresponsive genes (62). In macrophages and DCs the NF-kB pathway responds to different stimuli in a cell-specific manner by activating unique signalling pathways and subsets of NF-kB target genes (63).

Significant physiological and physiopathological consequences have been associated with NO production by skin cells. Nitric oxide appears to be involved in skin physiology, growth and remodeling (15-18). Being diffusible across cells, NO produced by LCs regulates lymphocyte proliferation by inhibiting or inducing apoptosis $(22,23)$. Nitric oxide is also involved in skin inflammatory processes (19-21), and a significant increase in iNOS protein was found in both irritant and allergic contact dermatitis (64). Therefore, NO produced by DCs may play an important role in modulating the allergic dermatitic response to contact allergens. A better knowledge of the signaling pathways activated by contact sensitizers in skin DCs, namely those involved in iNOS expression, will contribute to the identification of potential sites of therapeutic intervention.

\section{Acknowledgements}

We thank Dr G. Girolomoni (Laboratory of Immunology, Instituto Dermopatico dell'Immacolata, IRCCS, Rome, Italy) for the kind gift of the fetal skin derived dendritic cell line.

This work was supported by POCTI/1999/MGI/36373.

\section{References}

1. Bancherau J, Steinman R M. Dendritic cells and the control of immunity. Nature 1998: 392: 245-252.

2. Caux C. Pathways of development of human dendritic cells. Eur J Dermatol 1998: 8: 375-384.

3. Arrighi J-F, Rebsamen M, Rousset F, Kindler V, Hauser C. A critical role for p38 mitogen-activated protein kinase in the maturation of human bloodderived dendritic cells induced by lipopolysaccharide, TNF- $\alpha$, and contact sensitizers. J Immunol 2001: 166: 3837-3845.

4. Rescigno M, Martino M, Sutherland C L, Gold M R, Ricciardi-Castagnoli P. Dendritic cell survival and maturation are regulated by different signaling pathways. J Exp Med 1998: 188: 2175-2180.

5. Oyama T, Ran S, Ishida T, et al. Vascular endothelial growth factor affects dendritic cell maturation through inhibition of nuclear factor-kappa $B$ activation in hemopoietic progenitor cells. J Immunol 1998: 160: 1224-1232.

6. Ammon C, Mondal K, Andreesen R, Krause S W. Differential expression of the transcription factor NF-kappaB during human mononuclear phagocyte differentiation to macrophages and dendritic cells. Biochem Biophys Res Commun 2000: 268: 99-105.

7. Neumann M, Fries H, Scheicher C, et al. Differential expression of Rel/NF-kappaB and octamer factors is a halmark of the generation and maturation of dendritic cells. Blood 2000: 95: 277-285.

8. Liden C, Wahlberg J E, Maibach H I, et al. Skin. In: Goyer R A, Klausen C D, Waalkes M P, eds. London: Academic Press, 1995: 447.

9. Manome H, Aiba S, Tagami H. Simple chemicals can induce maturation and apoptosis of dendritic cells. Immunol 1999: 98: 481-490.

10. Aiba $\mathrm{S}$, Manome $\mathrm{H}$, Tagami $\mathrm{H}$. In vitro treatment of human transforming growth factor-betal-treataed monocyte-derived dendritic cells with haptens can induce the phenotypic and functional changes similar to epidermal Langerhans cells in the initiation phase of allergic contact sensitivity reaction. Immunol 2000: 101: 68-75.

11. De Smedt A C, Van Den Heuvel R L, Zwi Berneman N, Schoeters G E. Modulation of phenotype, cytokine production and stimulatory function of CD34+derived $\mathrm{DC}$ by $\mathrm{NiCl}$ (2) and SDS. Toxicol Vitro 2001: 15: 319-325.

12. Cruz M T, Duarte C B, Gonçalo M, Carvalho A P, Lopes M C. LPS induction of IkB- $\alpha$ degradation and iNOS expression in a skin dendritic cell line is prevented by the Janus kinase 2 inhibitor, tyrphostin B42. Nitric Oxide: Biol Chem 2001: 5: 53-61.

13. Cruz M T, Duarte C B, Gonçalo M, Figueiredo A, Carvalho A P, Lopes M C. Granulocyte-macrophage colony-stimulating factor activates the transcription of nuclear factor kappa B and induces the expression of nitric oxide synthase in a skin dendritic cell line. Immunol Cell Biol 2001: 79: 590-596. 
14. Lamas S, Pérez-Sala D, Moncada S. Nitric oxide: from discovery to the clinic. Tips 1998: 19: 436-438.

15. Heck D E, Laskin D L, Gardner C R, Laskin J D. Epidermal growth factor suppresses nitric oxide and hydrogen peroxide production by keratinocytes. Potential role for nitric oxide in the regulation of wound healing. J Biol Chem 1992: 267: 21277-21280.

16. Bruch-Gerharz D, Ruzicka T, Kolb-Bachofen V. Nitric oxide in human skin: current status and future prospects. J Invest Dematol 1998: 110: 1-7.

17. Krischel V, Bruch-Gerharz D, Suschek C, Kröncke K-D, Ruzicka T, Kolb-Bachofen V. Biphasic effect of exogenous nitric oxide on proliferation and differentiation in skin derived keratinocytes but not fibroblasts. J Invest Dermatol 1998: 111: 286-291.

18. Thornton F J, Schäffer M R, Witte M B, et al. Enhanced collagen accumulation folowing direct transfection of the inducible nitric oxide synthase gene in cutaneous wounds. Biochem Biophys Res Commun 1998: 246: 654-659.

19. Morhenn V B. Langerhans cells may trigger the psoriatic disease via production of nitric oxide. Immunol Today 1997: 18: 433-435.

20. Ross R, Gillitzer C, Kleinz R, et al. Involvement of NO in contact hypersensitivity. Int Immunol 1997: 10: 61-69.

21. Rowe A, Farrel A M, Bunker C B. Constitutive endothelial and inducible nitric oxide synthase in inflammatory dermatoses. Br J Dermatol 1997: 136: 18-23.

22. Genaro A M, Hortelano S, Alvarez A, Martínez A C, Boscá L. Splenic B lymphocyte programmed cell death is prevented by nitric oxide release through mechanisms involving sustained Bcl-2 levels. J Clin Invest 1995: 95: 1884-1890.

23. Lu L, Bonham C A, Chambers F G, et al. Induction of nitric oxide synthase in mouse dendritic cells by IFN- $\gamma$, endotoxin, and interaction with allogeneic $\mathrm{T}$ cells. Nitric oxide production is associated with dendritic cell apoptosis. J Immunol 1996: 157: 3577-3586.

24. Aiello S, Noris M, Piccinini G, et al. Thymic dendritic cells express inducible nitric oxide synthase and generate nitric oxide in response to self-and alloantigens. J Immunol 2000: 164: 4649-4658.

25. Paolucci C, Rovere P, De Nadai C, Manfredi A A, Clementi E. Nitric oxide inhibits the tumor necrosis factor alpha-regulated endocytosis of human dendritic cells in a cyclic GMP-dependent way. J Biol Chem 2000: 275: 19638-19644.

26. Heitmeier M R, Scarim A L, Corbett J A. Doublestranded RNA-induced inducible nitric-oxide synthase expression and interleukin-1 release by murine macrophages requires NF-kB activation. J Biol Chem 1998: 273: 15301-15307.

27. Wisdom R. AP-1: one switch for many signals. Exp Cell Res 1999: 253: 180-185.

28. Xie Q, Kashiwabara Y, Nathan C. Role of transcription factor NF-kB/Rel in induction of nitric oxide synthase. J Biol Chem 1994: 269: 4705-4708.

29. Kuo P C, Abe K Y, Schroeder R A. Oxidative stress increases hepatocyte iNOS gene transcription and promoter activity. Biochem Biophys Res Commun 1997: 234: 289-292.

30. Chen F E, Ghosh G. Regulation of DNA binding by Rel/NF-kB transcription factors: structural views. Oncogene, 1999: 18: 6845-6852.

31. Girolomoni G, Lutz M B, Pastore S, Abmann C U, Cavani A, Ricciardi-Castagnoli P. Establishment of a cell line with features of early dendritic cell precursors from fetal mouse skin. Eur J Immunol 1995: 25: 2163-2169.

32. Green L C, Wagner D A, Glogowski J, Skipper P L, Wishnok J S, Tannenbaum S R. Analysis of nitrate, nitrite, and $\left[{ }^{15} \mathrm{~N}\right]$ nitrate in biological fluids. Anal Biochem 1982: 126: 131-138.

33. Mittal C K, Harrel W B, Metha C S. Interaction of heavy metal toxicants with brain constitutive nitric oxide synthase. Mol Cell Biochem 1995: 149-150: 263-265.

34. Palumbo A, Astarita G, Picardo M, d'Ischia M. Ni $(2+)$, a double-acting inhibitor of neuronal nitric oxide synthase interfering with 1 -arginine binding and $\mathrm{Ca}$ $(2+)$ /calmodulin-dependent enzyme activation. Biochem Biophys Res Commun 2001: 285: 142-146.

35. Tian L, Lawrence D A. Metal-induced modulation of nitric oxide production in vitro by murine macrophages: lead, nickel and cobalt utilize different mechanisms. Toxicol Appl Pharmacol 1996: 141: 540-547.

36. Kawanishi S, Inoue S, Oikawa S, et al. Oxidative DNA damage in cultured cells and rat lungs by carcinogenic nickel compounds. Free Radic Biol Med 2001: 31: $108-116$.

37. Cruz M T, Duarte C B, Gonçalo M, Carvalho A P, Lopes M C. Involvement of JAK2 and MAPK on type II nitric oxide synthase expression in skin-derived dendritic cells. Am J Physiol 1999: 277: C1050-C1057.

38. Verhasselt V, Buelens C, Willems F, Groote D, Haeffner-Cavaillon N, Goldman M. Bacterial lipopolysaccharide stimulates the production of cytokines and the expression of costimulatory molecules by human peripheral blood dendritic cells. Evidence for a soluble CD14-dependent pathway. J Immunol 1997: 158: 2919-2925.

39. Ardeshna K M, Pizzey A R, Devereux S, Khwaja A. The PI3 kinase, p38 SAP kinase, and NF-kB signal transduction pathways are involved in the survival and maturation of lipopolysaccharide-stimulated human monocyte-derived dendritic cells. Blood 2000: 96: 1039-1046.

40. Valk E, Zahn S, Knop J, Becker D. JAK/STAT pathways are not involved in the direct activation of antigen-presenting cells by contact sensitizers. Arch Dermatol Res 2002: 294: 163-167.

41. Goebeler M, Roth J, Brocker E B, Sorg C, SchulzeOsthoff K. Activation of nuclear factor-kappa B and gene expression in human endothelila cells by the common haptens nickel and cobalt. J Immunol 1995: 155: 2459-2467.

42. Goebeler M, Gillitzer R, Kilian K, et al. Multiple signalling pathways regulate NF-kB-dependent transcription of the monocyte chemoattractant protein-1 gene in primary endothelial cells. Blood 2001: 97: 46-55.

43. Barchowsky A, Soucy N V, O’Hara K A, Hwa J, Noreault T L, Andrew A S. A novel pathway for nickel-induced interleukin-8 expression. J Biol Chem 2002: 277: 24225-24231.

44. Andrew A S, Klei L R, Barchowsky A. AP-1 dependent induction of plasminogen activator inhibitor-1 by nickel does not require reactive oxygen. Am J Physiol Lung Cell Mol Physiol 2001: 28: L616-L623.

45. Goebeler M, Meinardus-Hager G, Roth J, Goerdt S, Sorg C. Nickel chloride and cobalt chloride, two common contact sensitizers, directly induce expression of 


\section{Cruz et al.}

intercellular adhesion molecule-1 (ICAM-1), vascular cell adhesion molecule-1 (VCAM-1), and endothelial leucocyte adhesion molecule (ELAM-1) by endothelial cells. J Invest Dermatol 1993: 100: 759-765.

46. Pahl H L. Activators and target genes of Rel/NF-kB transcription factors. Oncogene 1999: 18: 6853-6866.

47. Allen R G, Tresini M. Oxidative stress and gene regulation. Free Radic Biol Med 2000: 28: 463-499.

48. Chen F, Shi X. Intracellular signal transduction of cells in response to carcinogenic metals. Crit Rev Oncol Hematol 2002: 42: 105-121.

49. Buzard G S, Kasprzak K S. Possible roles of nitric oxide and redox signalling in metal-induced toxicity and carcinogenesis: a review. J Environ Pathol Toxicol Oncol 2000: 19: 179-199.

50. Huang C, Li J, Costa M, et al. Hydrogen peroxide mediates activation of nuclear factor of activated $\mathrm{T}$ cells (NFAT) by nickel subsulfide. Cancer Res 2001: 61: 8051-8057.

51. Berghe V, Plaisance S, Boone E, et al. p38 and extracellular signal-regulated kinase mitogen-activated protein kinases pathways are required for nuclear factor-kB p65 transactivation mediated by tumor necrosis factor. J Biol Chem 1998: 273: 3285.

52. Carter A B, Knudtson K L, Monick M M, Hunninghake $\mathrm{G} \mathrm{W}$. The p38 mitogen activated protein kinase is required for NF-kB-dependent gene expression. the role of TATA-binding protein (TBP). J Biol Chem 1999: 274: 30858.

53. Balasubramanian S, Efimova T, Eckert R L. Green tea polyphenol stimulates a Ras, MEKK1, MEK3, and p38 cascade to increase activator protein 1 factordependent involucrin gene expression in normal human keratinocytes. J Biol Chem 2002: 277: 1828-1836.

54. Cruz M T, Duarte C B, Gonçalo M, Figueiredo A, Carvalho A P, Lopes M C. Differential activation of nuclear factor kappa B subunits in a skin dendritic cell line in response to the strong sensitizer 2,4-dinitrofluorobenzene. Arch Derm Res 2002: 294: U19-U25.
55. Yoshimura S, Bondeson J, Brennan F M, Foxwell B M J, Feldmann M. Role of NF-kB in antigen presentation and development of regulatory $\mathrm{T}$ cells elucidated by treatment of dendritic cells with the proteasome inhibitor PSI. Eur J Immunol 2001: 31: 1883-1893.

56. Giannoukakis N, Bonham C A, Qian S, et al. Prolongation of cardiac allograft survival using dendritic cells treated with NF-kB decoy oligodeoxyribonucleotides. Mol Ther 2000: 1: 430-437.

57. St Louis D C, Woodcock J B, Fransozo G, et al. Evidence for distinct intracellular signaling pathways in CD34+ progenitor to dendritic cell differentiation from a human cell line model. J Immunol 1999: 162: 3237-3248.

58. Clark G J, Gunningham S, Troy A, Vuckovic S, Hart D N. Expression of the RelB transcription factor correlates with the activation of human dendritic cells. Immunol 1999: 98: 189-196.

59. Burkly L, Hession C, Ogata L, et al. Expression of relB is required for the development of thymic medulla and dendritic cells. Nature 1995: 373: 531-536.

60. Pettit A R, Quinn C, MacDonald K P A, et al. Nuclear localization of RelB is associated with effective antigenpresenting cell function. J Immunol 1997: 159: 3681-3691.

61. Lee J I, Ganster R W, Geller D A, Burckart G J, Thomson A W, Lu L. Cyclosporine A inhibits the expression of costimulatory molecules on in vitrogenerated dendritic cells: association with reduced nuclear translocation of nuclear factor kappa B. Transplantation 1999: 68: 1255-1263.

62. Mercurio F, Manning A M. Multiple signals converging on NF-kB. Current Opinion Cell Biol 1999: 11: 226-232.

63. Baltathakis I, Alcantara O, Boldt Dh. Expression of different NF-kB pathways genes in dendritic cells or macrophages assessed by gene expression profiling. J Cell Biochem 2001: 83: 281-290.

64. Ormerod A D, Dwyer C M, Reid A, Copeland P, Thompson W D. Inducible nitric oxide synthase demonstrated in allergic and irritant contact dermatitis. Acta Derm Venereol 1997: 77: 436-440. 